\title{
DIE WESE, DOEL EN BELANGRIKHEID VAN LIGGAAMLIKE OPVOEDING IN 'N MODERNE KULTURELE SAMELEWING EN DIE PRINSIPIËLE GRONDBEGINSELS WAAROP DIT MOET BERUS*
}

Omdat die begrip Liggaamlike Opvoeding in die alledaagse taalgebruik ligtelik assosieer word o.a. met sulke begrippe soos sport, liggaamsoefeninge, in Engels met physical culture; in Duits met kôrpererziehung; in Grieks met gymnastiek en ander moontlike misleidende begrippe in aanverwante tale, en omdat in die alledaagse spreektaal daar wanopvattings ook kan bestaan i.v.m. so ' $n$ begrip soos kultuur, wil ons dan ten einde misverstand uit dic weg te ruim, vir eers kortliks nagaan wat presies onder die begrippe Kultuur en Liggaamlike Opvoeding verstaan moet word voordat 'n poging aangewend word om bogenoemde onderwerp te ondersoek.

\section{Die begrippe Kultuur en Liggaamlike Opvoeding (L.O.)}

Om die wese van die begrip kultuur beter te kan doorgrond moet dit teenoor sulke begrippe soos Natuur. en Beskawing gestel word.

Die begrip Natuur het betrekking op die kosmiese geskapene. Soos dit onder dic vloek van die sondeval daaruit sien met sy opbrengs van distels en doorns; voortvloeiende vermorseling van die kop van die slang; in smart kinders baar; in die sweet van die aanskyn brood eet; en die verganklikheid van die vlees... „ten dage as gij daarvan eet zult gij den dood sterven". Hierteenoor stel ons die begrip kultuur. Die woord kultuur is afkomstig van die Latynse woord "Cultura" wat beteken „verbouing". Om nou uit die natuur kultuur te skep

* Die skrywer is hoof van die Departement Lig. Opv. aan die U.O.V.S. 
beteken letterlik: oor die natuur te heers en dit te onderwerp d.w.s. diensbaar te maak vir gerief en gemak; dit te verfraai, daarin orde te skep en daaruit skoonheid te voorskyn te bring. In oordraaglike sin ... die neerslag van geestesgoedere, dat na ' $n$ lang fisiese worsteling teen die natuur, op geestelike gebied eiendom van die mense van 'n bepaalde tyd geword het.

Hieruit kan afgelei word, soos ons ook straks sal poog om aan te toon, dat elke tydperk in die geskiedenis sy eie tiperende kultuurbydraes gelewer het.

Hierdie geestes-kultuurgoedere wat eie aan 'n volk is en wat in die stoflike worstelstryd met die natuur, verower, deur wetenskap, godsdiens en kuns bevrug is, moet gepreserveer word en aan die jongere geslagte oorgedra-oorgelewer word in die opvoeding, gewoontes, sedes en tradisies. Ja moet selfs, omdat dit iets eie en heiligs aan 'n volk is, deur oorloë verdedig word soos die geskiedenis ook inderdaad bewyse van gelewer het.

Die term „,beskawing" is afkomstig van die werkwoord "skaaf", wat verwys na 'n fisiese gelykmakingsproses met as doel die verwydering van die nuwe onreëlmatige, skurwe oppervlaktes nadat die kwaste, splinters, knoeste verwyder is. In letterlike $\sin$ kom die begrippe beskawing en kultuur hierin ooreen dat beide die uiterlike verfraaiing en diensbaarmaking tot gerief en genot vir die mens beoog, in oordraaglike sin die verwydering van dit wat innerlik kan kwes of seermaak, ter bevordering van 'n ordelike samelewing. Saamgevat kom dit hierop neer dat kultuur of beskawing betrekking het op die eerste groot werkopdrag, Genesis 1 : 28, d.w.s. om nie net oor die natuur as kosmiese verskynsel te heers en dit te onderwerp nie, maar eweseer oor die eie natuur, en dit tot onderwerping te bring in ooreenstemming met sekere estetiese, etiese en religieuse eise.

Wat die begrip Liggaamlike Opvoeding betref moet toegegee word dat dit inderdaad misleidend is en verskillende interpretasies moontlik maak. In die reël is die neiging om die aksent op die byvoeglike naamwoord te laat val asof diegene wat hul met die vak besig hou, dan 'n opvoeding van die liggaam as kosmiese natuur- 
verskynsel sou nastreef, in die sin van 'n letterlike bo skawing d.w.s. uiterlike verfraaiing met behulp o.a. van kosmetiese middels. Alhoewel dit deels taak van die L.O. is, met sekere prinsipiële voorbehoude soos later sal blyk, is L.O. baie meer omvattend, daar dit die opvoeding van die totale mens as psigo-fisiese totaliteit beoog (in die sin van die oordraaglike betekenis van die woord beskawing) met die liggaam slegs as aanknopingsen uitgangspunt. Die opvoeding moet êrens begin, êrens aansluiting vind. Waar die tradisionele skoolopvoeding by die verstand of intellek; die godsdienstige vorming by die siel aanknoop; knoop die L.O. aan by die liggaam uit praktiese oorwegings, omdat in die biologiese ontwikkeling van die mens, wat alle ander ontwikkeling voorafgaan, die liggaam as voorwaarde geld.

In die geskiedkundige ontwikkeling van die vak L.O. meen ons by magte te wees om die oorgangstadiums van die letterlike na die figuurlike betekenis van die begrippe kultuur en beskawing soos bo geskets, en van toepassing op die bemoeiinge met die opvoeding van die mens, aan te toon.

Om hierdie stelling te bewys wil ons vir eers stilstaan by die direkte doelstelling van die liggaamsoefeninge, waarin die volgende drie fases van ontwikkeling openbaar word, nl. die oefening van die liggaam met as doel: ontspanning, gesondheid en sport; om vervolgens by die indirekte doelstelling aan te toon dat die oefening van die liggaam nodig was maar in diens gestaan het van 'n verhewener doelstelling, nl. magies-religieuse strewe, staatkundige selfhandhawing en harmonieuse ontwikkeling van die mens as organiese eenheid, liggaam-siel, in die sin soos in dic L.O. van toepassing.

\section{Direkte doelstelling}

(i) Oefening van die liggaam met ontspanning as doel As ons die natuurvolkere gadeslaan in hul natuurlike liggaamsbeweginge en spele sal by die eerste oogopslag hieraan alle doelgerigtheid ontbreek. Al rede wat ons van hierdie skynbaar doellose aktiwiteite kan aanvaar is 
dat dit ' $n$ veiligheidsklep moet vorm vir momentane oortollige energie. Hierdie verskynsel doen hom ook voor by die ongekunstelde kind. By nadere oordenkinge en studie is dit egter duidelik dat hierdie sogenaamde doellose liggaamsbeweginge van die kind sowel as van die natuurmens tog doelmatig is. Dit blyk dat die onbewuste doel van hierdie bewegings is, soos ook deur Schiller, Karl Groos en Spencer onderskryl, om die nodige groeiprikkels te lewer vir die bevordering van die biologiese groei en ontwikkeling van die mens.

Waar die moderne mens as gevolg van 'n ultra-gekunstelde stadsamelewing, oorbevolking en gebrek aan bewegingsmoontlikhede, verstoke is van die natuurlike groeiprikkels, word kunsmatige liggaamsoefeninge as surrogaat tocgepas as 'n teëwig teen die versteurde vitale biologiese ontwikkeling. Liggaamsoefeninge word nou in die natuur in die vorm van wandeltogte en opelugverkeer voorgeskryf. Dit word as ontspanning tipeer.

Dis tog duidelik dat hierdie eensydige doel van sintuiglike gewaarwordingsgenot wat die eindresultaat van ontspanning is, nic as eindpunt van ons opvoeding aanvaar kan word nie. Alle L.O. wat hierop baseer word beklemtoon die mens se wese eensydig en wil beskawing in die letterlike sin bevorder.

(ii) Oefening van die liggaam met gesondheid as doel In nou verband met hierdic gemelde doel kan as doel van die liggaamsoefening ook aangevoer word die herstel en behoud van dic gesondheid. Die feit dat met die oefening van die liggaam vir hierdie oogmerk 'n hoë graad van doelbewuste handeling gebaseer op redelike kennis van die Anatomic en Fisiologie vereis word, bewys dat hier ' $n$ verhewener doel nagestreef word.

Die geskiedenis van die Sjinese maak melding van keisers wat die volk sekere krygsoefeninge en danse laat uitvoer het ter behoud van die openbare gesondheid. Uit hierdie tydperk dateer die Teorie van Confucius waar 'n metode ontwerp is om sekere liggaamsoefeninge met longwerking te verbind. Volgens die Teorie moes opsetlike asemhalingsoefeninge volgens voorskrif gegee word. 
Hierdie oefeninge het weinig aantrekliks gehad, omdat aan die oefenreekse bepaalde genees- en heelkundige waarde geheg is en dit alleen aan siekes voorgeskryf is.

Hippokrates, die vader van die geneeskunde (460377 v.C.), het die liggaamsoefeninge nie net as 'n geneesmiddel toegepas nie maar dit ten sterkste aanbeveel as middel ter behoud van dic gesondheid.

Plato (428-347 v.C.) het herhaaldelik op die waarde van gimnastiek en geneeskunde vir die versorging van die liggaam gewys. Volgens hom het hulle 'n gemeenskaplike doel gehad, nl. die herstel en bevordering van die gesondheid. Terwyl die geneeskunde die gesondheid probeer herstel het deur kunsmatige middels (medisyne en chirurgiese behandeling verbind met dieet), het die gimnastiek dit langs natuurlike weg probeer bereik, d.w.s. liggraamsoefeninge verbind met dieet.

Dat die behoud van die gesondheid enersyds deur die gimnastiek gewaarborg is, dog andersyds afhanklik was van die reiniging van die liggaam, word bewys deur die inrigting van die Griekse gimnasium. Aan elke gimnasium was ' $n$ uitgebreide badinrigting verbonde en alle oefeninge het met ' $n$ bad ge ̈indig. $\mathrm{Na}$ die bad het hulle hul met olie ingevryf en kon hulle, deur die bad verfris en met olie gesalf, met nuwe lewenslus veerkragtig en met gemak hul gewone take aanvaar. Met die verval van die sedes het hier egter 'n ontaarding in die badpraktyke ingetree. Hierdie goeic praktyk het plek gemaak vir onsedelike optrede. Soos diere het hulle hul liggame in die lou baddens oorgegee. Sodomie het hoogty gevier. Op hierdie stadium van verval het die Romeine die praktyk oorgeneem en omdat hul dit op diesclfde lees geskoei het, het die ontaarding by die thermae sulke afmetings aangeneem dat die badplekke gesluit moes word omdat hulle broeineste van aansteeklike siektes en verderf van alle goeie sedes geword het.

Ook die Realiste het die nuttigheid van liggaamskultuur (soos hulle die gimnastiek genoem het) beklemtoon, al was dit dan ook net uit die enige utiliteitsoogpunt - die behoud van die gesondheid merendeels om te 
verhoed dat die verstand in sy werking deur 'n siek liggaam belemmer word.

Hierdie doelstelling sal ons ook as te eng en eensydig vir 'n opvoedkundige stelsel bestempel. Watter waarborg word in hierdie stelsel gelewer dat die ontketende kragte, luste, neigings en drifte (die gevolg van 'n blakende gesondheidstoestand) onder ' $n$ sentrale beheer is en nie die bestaande welvoeglikheidsgrense sal oorskry nie? Een gevoel van overmaat van kracht, lokt uit tot geweldenary, tot brutaliteit en wellust (Kuyper). Ook hier weer word die letterlike beskawing bevorder.

\section{(iii) Liggaamsoefening met sport as doel}

Nog ' $n$ ander doel wat by die liggaamsoefeninge nagestreef kan word is die ten toppunt gedrewe sportbeweging - waar die najaging van die hoogste prestasie in sy uiterste vorm in rekordslaan ontaard het.

Van die vroegste tye af was dit die gebruik by feesgeleenthede dat die gesonde lewenslustige jongmense geleenthede gevind het om in 'n sportiewe gees onderling kragte te meet. Hierdie mededingingsywer het later in die meer geordende lewe van die beskaafde volkere groter eise gestel ter bevrediging. Spesiale sportbyeenkomste is gereël wat deelnemers van heinde en ver gelok het. Die oorwinnaars is met olyfkranse bekroon en as helde vereer. Dit was die gebruik by die ou Grieke toe hulle gimnastiek nog sy edele strekking gehad het. Ten tyde van die verval (miskien was die oordrewe sport die oorsaak van die verval) het hierdie gesellige sportfeesbyeenkomste ontaard in agonistiek (wedstrydsport), en later nog laer gedaal tot atletiek (pankration). Atletiek was nou uitsluitlik deur diegene beoefen wat die liggaamsoefening nie as opvoedingsmiddel aangewend het nie - maar in die diens van die sport gebruik het ten einde daarmee roem en wins te behaal. Die eintlike beroepsatlete - hulle wat van die een fees na die ander gegaan het met die doel om pryse te verower - het gewoonlik 'n reusagtige liggaamsbou en buitengewone liggaamskragte gehad. Dit was in hulle belang om die 
liggaam in omvang en gewig soveel moontlik te laat toeneem.

Sulke afmetings het die eensydige sport aangeneem dat selfs die beroemde arts Galenus dit sy plig geag het om 'n waarskuwende woord te laat hoor. Volgens hom was die lewe van die atlete 'n sirkelgang van eet, drink, slaap en rondtol in die sand. Hulle kon nòg op welgevormdheid, nòg op gesondheid roem. Hulle liggame was mismaak deur verrekking en verminking, en alhoewel hul in staat was om ongewone kragtoere te verrig, kon hulle nie die geringste weerstand bied teen siekte, hitte of koue nie.

Die hoogtepunt was bereik in die Romeinse sport waar, by die gevegte soos in die maand Maart ter ere van Minerva, dit 'n uiters bloedige verloop gehad het. Hierdie tonele het 'n onuitwisbare vlek op die goeie sedes van die volk nagelaat. Onder die Romeinse keisers is hierdie afskuwelike tonele as groot vermaaklikheid beskou, en die volk het hierna met 'n soort raserny uitgesien. In die amfiteaters het gevegte tussen mense en wilde diere plaasgevind. Dit blyk ook in die behae wat die volk geskep het in die doodstryd van Christenmartelare met wilde diere, 'n stryd nie deur hulle gekies nie maar aan hulle opgedring.

Die Romeinse gepeupel het slegs twee dinge van die owerheid verlang - brood en sirkusse of spele. Net soos hierdie stand van sake in die Romeinse tyd 'n absolute laagwatermerk bereik het, so is die huidige toestand nie veel beter nie. Ons stel een van die moderne sportkritici aan die woord:

„Das heutige Streben nach Höchstleistungen, nach Rekorden, führt in mancherlei Formen auf Abwege. Das Berufsarbeiten der Rekordleistungen ist meist nicht möglich ohne tage-, ja wochenlanges einseitiges Training. Der Rekordmensch ist deshalb meist für Tage, ja Wochen, besonders wenn er noch auf Reisen geht, als dienendes Glied der wirtschaftlichen Gesellschaft ausgeschlossen. Meist ist es auch so, dasz viele dieser Leute, die Sonntag für Sonntag von Kampf zu Kampf ziehen, auch trotz und während ihrer Anwesenheit im Geschäft für dieses kein 
wertvolles Glied sind. Ihre Gedanken weilen oft anderswo; ihre Arbeit kann unmöglich befriedigend sein. In dieser Beziehung dürfen wir die Presse nicht gansz für unschuldig erklären. Nur zu oft ist sie auf das Sensationelle eingestellt. Ihre Berichte nehmen die Phantasie und Gedankengänge der jungen Menschen gansz in Beschlag. Sehr haufig kommt es dazu, dasz diese jungen Menschen in ihrer freien Zeit für andere, nämlich geistige Probleme, z.B. für Kurse, die ihrer beruflichen Weiterbildung dienen, keine Zeit und kein Interesse mehr haben. Es ist kaum möglich, dasz einseitige Hypertrophie eines Teiles des Menschen sich nicht ohne Schaden für den Gesamtmenschen entwickeln kann. Hypertrophie des Bewegungsapparates schwächt, ja atrophiert den geistigen Menschen. Gerade geistige konzentrierte Höchstleistungen sind mit muskularer Hypertrophie unvereinbar."

Beslis moet ons hierdie eensydige doelstelling vir die L.O. verwerp as te eng gebonde aan die letterlike betekenis van die woord beskawing.

Die mens tog is 'n liggaam-siel wese en daarby is vir die gelowige die liggaam ook nog die tempel van die Heilige Gees. Nòg die liggaam, nòg die gees mag verneder word tot 'n sensasiemiddel.

\section{Indirekte doel van die liggaamsoefeninge}

(i) Die magies-religieuse doel

Hier kry die liggaamsoefeninge eers sin en betekenis as dit in diens van 'n hoër doel gestel word. Hier is die liggaam nie meer doel op sigself nie maar word dit middel waardeur 'n ryk innerlike gevoed word - die kultuur in oordraaglike betekenis.

Dis ' $n$ oorbekende feit dat die natuurvolkere hulle blydskap of verdriet langs die weg van liggaamlike bewegings, danse of bewegingskunste, soek te vertolk. Laasgenoemde word beoefen wanneer hul hul gode dankbaarheid wil betoon of om genade smeek.

Die liggaamsoefeninge van die Sjinese het ten dele wel 'n gesondheidstendens gehad, maar is ten andere ook beoefen vir godsdienstige vorming. Die reeks mediese 
oefeninge bekend as Cong Fu, wat in Sjina in praktyk was 2600 v.C., is gebaseer op die teorie dat siekte die gevolg is van onaktiewe organe. Om die organe tot normale funksie te prikkel is sekere liggaamsoefeninge in verbinding met asemhalingsoefeninge voorgeskryl. Sodoende kon die lewe verleng word en is die onsterflikheid van die siel gewaarborg. Selfs die ou Germane het dergelike feeste gehou wat 'n magies-religieuse tendens gehad het. Dis ook bekend dat al die groot feesspele van die Grieke 'n godsdienstige karakter gedra het. As voorbeeld dien die Olimpiese Spele en die Nemeïese Spele ter ere van Zeus, die Pytiese Spele ter ere van Apollo, die Isthmiese ter ere van die seegod Poseidon, asook nog ander minder belangrike spele.

Hierdie naïewe godsverering, waar dans beskou was as gebed met die bene, het sy verskyning in vermomde gedaante in ons moderne gekunstelde lewe gemaak en wel in die vorm van die moderne kronkelslang-beweginge bekend onder die naam van Ritteldans. Hicr word die liggaam ook as uitclrukkingsmiddel gebruik, dog nic van 'n innerlike ryke lewe nie, maar slegs as nabootsing oppervlakkig meganies ingeoefende bewegings - om die innerlike bankrotskap te verberg. Onteenseglik het hierdie doelstelling vir die L.O. besliste waarde. Dit benadruk die eenheid van innerlike en uiterlike, terselfdertyd word ons egter gewaarsku teen die leegheid wat tog onder vecl grootdoenery kan skuil.

(ii) Staatkundige selfverdediging

Liggaamsoefeninge was noodsaaklik vir die natuurvolkere omdat die lewe 'n stryd om die bestaan was. By die ou Germane het die "Sippe" se voortbestaan op die verantwoordelikheid van elke afsonderlike lid gerus. Hulle was verplig om die liggaam te oefen omdat 'n swak skakel in die ketting van die "Sippe" die ondergang van die hele gemeenskap kon beteken in die onderlinge vete waar man teen man in die stryd te staan gekom het.

IHierdie doel van liggaamsoefeninge het weer prominent te voorskyn gekom onder Nasionaal-Sosialisme soos 
aangedui was in hul Richtlinien für die Leibeserziehung in Jugenschulen:

„Ziel und Inhalt der Erziehung ergeben sich aus der National Sozialischen Weltanschauung, die in Volksgemeinschaft, Wehrhaftigkeit, Rassebewustsein und Führertum die erhaltenden und bewegerden kräfte der Nation erkennt".

Van elke Duitser was 'n beroeps-,,Leistung" verlang, en kon hy dit nie lewer nie, het hy moreel geen reg gehad om te bestaan in die Nasionaal-Sosialistiese staat nie. As van hom die allerminste geëis word, nl. om in sy cie behoeftes te voorsien en hy dit nie kon doen nie, van watter nut is hy vir die staat of nasie wat volgens hulle ideologie die hoogste doel en strewe moes wees?

Ons moet hier slegs op die groot verskil wys wat daar bestaan het tussen die Nasionaal-Sosialisties geoefende nasielid en die geoefende Romeinse gladiator. Die motiewe verskil hemelsbreed. By die Romein was die doel suiwer om materiële wins te haal uit 'n vreemde se lyf en lewe, gepaard gaande met botviering van dierlike hartstogte. By die Duitser is dit liggaamlike tugtiging ter instandhouding van 'n geordende kollektiewe samelewing - volk, nasie, staat.

Hierdie doelstelling plaas die suiwer fisiese bestaan te hoog en kan ook nie deur ons L.O. as eindpunt aanvaar word nie. Nogtans leer dit ons dat die mens 'n groot verpligting het teenoor homself, asook teenoor sy voor- en nageslag. Hy vorm 'n skakel in die rashigiëneketting wat die nasie van die verlede met die van die toekoms verbind, en gevolglik is hy verplig om sy liggaam rein en onbesproke te bewaar, versadig en te oefen sodat dit nie as broeines van skadelike aansteeklike siektes die oorsaak mag wees vir die besmetting van sy nageslag nie.

(iii) Harmoniese ontwikkeling van die mens

Die hoogste doel wat in 'n stelsel van L.O. nagestreef kan word sal al die vorige eensydige doeleindes, in die regte verhouding, insluit. Dit beoog nie slegs die alsydige 
ontwikkeling van die liggaam nie maar wel die harmonieus ontwikkelde menslike wese en persoonlikheid.

'n Dergelike sisteem van L.O. is deur die ou Grieke toegepas. Die hoofdoel van hul gimnastick eweas van alle ander onderdele van dic opvoeding was om liggaamlik en geestelik, skone, kragtig gelykmatig ontwikkelde gesonde mense te vorm wat hul gode in volmaaktheid kon ewenaar.

Almal het die liggaamsoefeninge noodsaaklik geag om die ware harmonic tussen die liggaam en die siel te bewerkstellig. Almal het gestreef na liggaamlike skoonheid, gepaard gaande met geestelike en sedelike volmaaktheid. Heil gimnastick het onder die beskerming van die wette gestaan, was eg nasionaal en het as middel gedien om hul selfstandigheid te bewaar en te handhaaf.

Dat hierdie doel verwesentlik is, getuig die hoë ontwikkeling van die Helleense volk, wat in liggaamlike skoonheid en geskiktheid in die kryg, staatsinrigtings, filosofie, poësie en plastiese kuns tot uiting gekom het.

Hierdie klassieke plekkie grond bewys op glansryke wyse watter invloed ' $n$ alsydige opvoeding op 'n volk kan uitoefen. Die klein Griekeland was magtig en groot. Die handjievol Hellene wat die land bevolk het was manne, waardige burgers van vrye stadstate. Uit hulle het die groot denkers gekom vir wie ons vandag nog die hoogste agting koester. Dis hulle wat die geesdrif by die kunstenaars gewek het om kunswerke tot stand te bring wat tot vandag toe nog nie geëwenaar is nie. In hulle tyd het hulle boukundiges die onsterflike lyne en verhoudings vasgestel wat vandag nog as norme geld. Dic gimnastiek het die volk krag, moed en liefde vir die verhewene en skone gegee. Die gimnastiek was die voedingsbron van die magtige vrye Hellas. Die ware gimnastiek vir almal, die stelselmatige oefeninge gebaseer op die destyds bekende wette van die liggaam en opsetlik vir die volksontwikkeling geskik gemaak, het Griekeland en die Hellene in die geskiedenis van die L.O. 'n ereplek besorg.

Hicrdie studie het tot dusver an die lig gebring dat liggaamsoefeninge as primêre doel nie reg tot aanspraak 
in 'n leerplan as opvoedingsmiddel het nie; eers dan kan dit in aanmerking hiervoor kom as dit die status van Liggaamlike Opvoeding bereik het.

Waar ons kortliks stilgestaan het by die wese en doelstelling van die L.O. in sy geskiedkundige ontwikkeling, wil ons vervolgens in hooltrekke die taak van 'n departement van Liggaamlike Opvoeding as akademiese aangeleentheid formuleer.

Daar is soveel stelsels van opvoeding as wat daar lewens- en wêreldbeskouings is. Beleidloosheid op die gebied van die L.O. aan ons hoëre inrigtings en skole (Suid-Afrika is die laaste dekade oorstroom deur vreemde ideologiee op die gebied) het as gevolg gehad dat ons owerheid 'n soort eklektiese stelsel, d.w.s. samellansing van verskeie oorsese stelsels, voorgestaan het, soos ook blyk uit die voorwoord deur die destydse Minister van Onderwys, Kuns en Wetenskap by die aanbieding van die eerste I.eerplan deur die Nasionale Adviserende Raad vir L.O.

Hierteenoor wil ons 'n positiewe stelsel daarstel wat eie is aan die lewens- en wêreldbeskouing van die Afrikaner en sy spreckwoordelike Godsdienssin. Daarom dan ook dat ons uitgangspunt baseer is op die onfeilbare Woord van God wat lecr... dat die mens geskape is na dic beeld en gelykenis van God, deur die sondeval getref is en sterflik geword het ... dat die mens nieteenstaande hier op aarde geplaas is ter ere en verheerliking van God met die opdrang om te heers en te onderwerp, d.w.s. kultuur te skep. Dit is gebaseer op 'n Christelike antropologiese leer wat inhou clat die mens 'n besondere plek tussen alle skepsels inneem. Engele is volgens die Heilige Skrif meteens volmaak geskape, hulle mak nie 'n ontwikkelingsproses deur om te kom waar hulle moet wees nie, hulle word nie, maar is volmaak geskape.

Aan die ander kant is diere wel aan die wet van ont wikkeling onderworpe. Hulle word gebore, groei op en sterf. By hulle is daar geen sprake van 'n doel, van 'n bestemming waarna gepoog moet word nie. Hulle word wat hulle moet wees, nie deur ' $n$ vrye daad nie maar deur 'n natuurproses en as hulle nie word wat van hulle 
verwag word nie is dit miskicn skadelik vir dic eienaar maar vir die dier self is dit onverskillig, omdat hy geen sedelike wese is nie en geen verantwoording hoef te doen in 'n hiernamaalse bestaan nic.

Dic mens daarenteen neem 'n besonder plek tussen cngele en diere in. Met die engele het hy 'n geestelik-redelike natuur gemeen. Hy is burger van die ryk van die ideë en gebind aan die sedewet. Hy bchoort iets te wees en is nie onverskillig wat hy sal word nie. Met dic diere is hy hicrin verwant dat hy wat hy beloort te wees langs die weg van ontwikkeling moet word. Hy word nie groot nie maar klein, nic oud nic maar jonk, nic volwasse nie, maar kind geborc. Hy bring 'n cic aanleg, vatbaarheid, geskiktheid mee en is dus geen tabula rasa nie. Hy is as kind reeds mens, maar mens in potensie, en het versorging en opvoeding nodig on tc word wat hy moet wees. Omdat hy deur niddel van sy liggaam deel het aan die diereryk, dog ook deur middel van sy onsterflike siel deel het aan dic geestelike ryk, ondat die mens dus 'n liggaam-siel wese is, 'n psigo-fisiese totaliteit, is die versorging wat hy nodig het tweeledig van aard. Vir sover hierdie versorging op die instandhouding van die liggaam of soma betrekking het, neem dit die vorm van voeding aan. Deur sy liggaam is die mens aan die aarde verwant, is hy aards uil dic aarde. Hicrsonder kan hy nie bestaan nie, hicrvan moet hy sy vocdsel en drank en deksel, sy lig en lug ontvang. Die aarde is dic groot voorraadskuur vir sy liggaamlike bchoeftes, dit is die gemeenskaplike kapitaal wat God aan die mensekinders gegee het waarvan hy moet lewe.

Maar cwe noodsaaklik as die versorging van die liggaam is ook dić van die siel. Die wcrksaamheid wat hiermee gemocid is word saamgevat onder die begrip opvoeding. Wat dic voeding vir die fisiese lewe van die inens is, is clie opvoeding clus vir sy bestaan as psigiessedelik-redelike wese, maar nie asof beide geskei en langs mekaar verloop nic, want ewe min as siel en liggaam is voeding en opvoeding van mekaar afskeidbaar, omdat die siel op die innigste wyse in die liggaam ingeskape is.

Voeding is daarom ook vir die psigiese lewe van 
betekenis en opvoeding strek sig tot die liggaam uit, beide is middels vir die instandhouding en bevordering van die menslike lewe, maar elk en beide doen dit op eic wyse.

Dic geskiedenis leer egter dat hierdie waarheid telkemale verkrag is deurdat dic versorging van die gees of siel nie altyd en ten alle tye ewe belangrik was as die versorging van die liggaam nic en omgekeerd. Die primitief het 'n fisiese stryd teen die natuur gevoer vir die behoud van die lewe - versorging en versekering van die suiwer stoflike bestaansvoorwaardes. Al die krag van die organisme is vir beskutting teenoor vyande, teen invloede van weersgesteldheid en vir voedsel en voortplanting opgeëis. Sodat daar weinig krag oorgebly het vir die omsetting van besondere ervaringe in algemene insigte en begrippe en die verwerking van hierdie begrippe tot ervarings- en gecsteskapitaal. Die stryd is elke dag herhaal met inskakeling van honderd persent organiese arbeidsvermoë. Die liggaam het die gees verdring. Dit verklaar die lae peil van kultuurontwikkeling van daardie tyd. Met verloop van tyd het die mens sy daelikse broodwinningstryd omgeskep in 'n permanente oorwinning waardeur ' $n$ deel van dic fisiese stryd weggeval het en die oorwinning, op die lange duur, waardevol was. Teen die klimaat het die mens homself beveilig deur klere en wonings; vir voedsel is deur landbou en veeteelt voorsiening gemaak; vir transport is vervocrmiddels ontwerp; vir bestryding van die milieu - gereedskappe, vuur, wapens; swerf en soek na kos het oorbodig geword.

Vaste verblyfplekke waar alles wat nodig was vir die bestaan het ontstaan. Meer tyd en krag is hierdeur bespaar vir geestelike funksies soos waarneming, oordenking, organisering van ervaringe en gevoclens. Die gesinsverband is versterk, die groepsverband het sy verskyning gemaak, die somderwing het 'n geordende kulturele maatskappy geword.

Hierdie beweging van die vrymaking van die suiwer fisiese stryd gevoer met suiwer liggaamlike organe, het steeds verder voortgegaan en sy neerslag gevind in die huidige gekompliseerde samelewing waar alle aksent op 
die geestelike stryd geval het met uitskakeling van die fisieke stryd - altyd meer kultuur, altyd meer verwerking en bemeestering van kultuurgoedere van opvolgende geslagte.

Prinsipieel is daar met hierdie ontwikkelingsgang geen fout te vind nie. Sonder hierdie proses sou die mens nie sy volle roeping kon nagekom het nie en sou die beskawing-kultuur-maatskaplike ordening nie sy hoogtepunt bereik het nie. Maar ongelukkig dat die fisieke vorming en versorging beide in die bewuste sowel as die onbewuste opvoeding verwaarloos is. Die aksent is meer en meer verskuif na die voorbereiding vir die geestelike stryd en werksmiddels, d.w.s. geestelike weerbaarheid. Die individu moes aangepas wees aan die nuwe milieu en die nuwe milicu het geëis verstandsfunksie, geestelike skoling, terwyl dit geskied het ten koste van die fisiese bestaan. Die gees het die liggaam verdring. Dit verklaar die verskynsel van fisieke degenerasie: kenmerk van 'n modern kulturele samelewing.

Dis tog ' $n$ algemeen bekende feit dat ons vandag nie hoef te beskik oor buitengewone fisieke krag en arbeidsvermoë oor gevoelloosheid teenoor klimatologiese invloedc, gevoeligheid vir ongereelde voedingstye, in dieselfde mate as die primitiewe jagterstamme en nomadiese volkere nie. Maar sonder die stoflike substratum kan ons in hierdie lewe nie bestaan nie. Ons sal oor 'n sekere biologiese krag moet kan beskik om as kultuurdraers te kan voortgaan. Net soos die geestelike ontwikkeling eertyds skade gely het onder die druk van die fisieke prestasies wat van die mens vereis was, net so werk ons hedendaagse geestelike werksaamhede in ' $n$ moderne maatskappy belemmerend in op die normale fisieke ontplooiing en ontwikkeling.

Ons het van die een uiterste, roofbou, op die gees oorgegaan na dic ander uiterste, roofbou op die liggaam. As bewyse vir hierdie stelling kan aangevoer word ten eerste eie menslike ervaring wat ten tweede bevestig word deur wetenskaplike vasstelling en formulering van die betrokke feite. Hoeveel lewensgeluk is nie opgeoffer 
en vernietig deurdat die liggaam te swak is by onvolledige uitrusting om aan dic eise van die gees te voldoen nie? Wic ken nic voorbcelde uit eic ervaring van te vroeg afyebroke lewes of van jarclange lyding, van val en opstaan en van sickte nic? Wie kan die skade deur fisieke agteruitgang op ekonomiese gebied bereken? Beteken verlies van fisieke $\mathrm{krag}$ nic ook verlies van geestelike arbcidsvermoë nie? Ons weet uit ervaring dat die gees die liggaaml verdring het en ondervind self die skade aan die liggane. Spencer sê: „Kroniese liggaamlike steurnisse gooi 'n skadu oor die skitterendste vooruitsigte, terwyl lewenskrag en 'n sterk gesondheid nog in staat is om mislukkings en ongelukke te verguld".

Die gees het clic liggaam verdring, en omdat dit self daaronder skade ly moet middels gevind word om die liggaam weer tot sy reg te laat kom, anders sal die kultuurstryd ten gronde gaan.

Reeds te lank is lisicke swakte as 'n toestand beskou wat maar aanvaar moet word as iets wat nou cenmaal die lot van die mens hier op aarde is en wat met wetenskaplike middels bestry moet word. Oor die werklike oorsprong van dic kwaad, dic oursake, is nie besin nie. Die ontdekking van die oorsake is nie meer 'n vraagstuk van algemene crvaring nie maar van die wetenskap, en die wetenskap het die oorsaak van die fenomeen gevind, en wel in onvolledige liggaamlike ontwikkeling en belemmerde biologiese ontplooiing te wyte aan die feit dat die fisieke ryping on tot volwaardige eksemplaar van die soort te ontwikkel deur kultuuromstandighede onderdruk is. Hierdie ontdekking het aanleiding daartoc gegee dat middels gesoek word wat die fisicke ryping kan bewerkstellig om 'n moderne kultuur te waarborg. Die middel is gevind en sy bydracs is wetenskaplik ondersoek en as geskik vir gebruik aanbeveel deur vurige profetc, pedagoë en higiëniste, maar helaas nic met die nodige geesdrif in die opvoeding tocgepas nie. Die middel is prinsipicel gerigte liggaamsoefeninge en die toepassing daarvan liggaamlike opvoeding (Korpershoek - Laatste drie eeuwen). 
Samevatting en toepassing. Prinsipiële beginsels waarop 'n akademiese kursus in die L.O. moet berus

Kragtens die eerste groot werkopdrag is ons geroep om te onderwerp en te heers, d.w.s. kultuur te skep. In letterlike sin, soos ons gesien het, het kultuur betrekking op die uiterlike beskawing, d.w.s. verwydering van die uiterlike hinderlike, dit wat steurend aandoen; bruikbaarmaking; verfraaiing en die skepping van skoonheid. In figuurlike sin die onderwerping van die eie natuur aan etiese, estetiese en religieuse eise, die neerslag waarvan uitkristalliseer het in gebruike, sedes, gewoontes, tradisies cie aan 'n volk.

In die toepassing van hicrdie beginsels het die L.O. 'n tweërlei talak en rocping, 'n direkte en 'n indirekte of oordraaglike. Wat die liggaam as kosmiese verskynsel betref is die direkte doelstelling die bevordering van die (i) gesondheid, wat deur die sondeval geknak is en wat a.g.v. dic eise van 'n moderne kulturele samelewing 'n aktuele vraagstuk geword het. Om aan hierdie aspek reg te laat geskied moet die L.O. as wetenskap hom laat lei deur die bevindinge van dic vakwetenskappe Anatomie, Sosiologic, Biologie, Higiëne en Voedingsleer. (ii) Wat ontspanning betref, wat vandag 'n ewe belangrike vraagstuk in 'n moderne kulturele samelewing geword het ten gevolge van outomatisasie en meganisasie, inkorting van werksure, meer ongelyk en a.g.v. samedromming van mense in stede, inperking van bewegingsruimte, staan ons voor die vraag of in die opvoeding nie ook met hicrdie vraagstuk rekening gehou moet word nie - d.w.s. om mense op te lei om die seëninge van vryetyd oordeelkundig te gebruik nie. As die mens nie aktief met een of ander vorm van 'n stokperdjic of sport besig gehou word nie, die smaak hiervoor nie reeds op skool aangekweek word nie, bestaan die moontlikheid dat die vryetyd in 'n Frankenstein-monster kan verander. Vir die moontlike implikasies van hierdie vraagstuk sal met dic Sosiologic as hulpwetenskap van die L.O. sowel as met die Kriminologic te rade gegaan en vir 'n moontlike oplossing sal die hulo van die moderne sport ingeroep 
moet word, want dis tog verkiesliker dat die moderne mens hom in sy vrye ure op weg na die sportveld, vir aktiewe deelname, sal bevind, eerder as dat hy in 'n donker gerookte kroeg of bioskoopsaal sy vryetyd sal verbeusel en nog boonop sy gesondheid daardeur sal ondermyn.

Maar aangesien deelname aan sport 'n hoogs gespesialiseerde onderbou veronderstel wat tegniese vaardighede betref, sal die kennis van die volgende wetenskappe hoogs noodsaaklik wees - Fisika, Toegepaste Fisiologie, Kinesiologie. Maar om te verhoed dat sportbeoefening en entoesiasme ten koste van geestelike waardes sal ontwikkel, sal die hulp van die normwetenskappe Filosofie, Teologie en dic Opvoedkunde ingeroep moet word.

Samevattend kan ons sê dat ons deels die beginsel van liggaamskultuur anvaar in soverre dit die diensbaarmaking van die liggaam beoog, d.w.s. geskiktheid tot arbeid, fiksheid tot die verrigting van alledaagse take, strenge dissiplinering in die gebruik van voedsel en drank, onthouding van dit wat die liggaam en gesondheid kan skaad en die weerstandsvermoë teen siektes kan verlaag. Maar ons verwerp beslis die aanwending van 'n oormaat van kosmetiese middels en praktyke om liggaamlike verval en aftakeling te verbloem, daar dit by die balsempraktyk tuishoort en ons herinner aan die spreekwoordelike witgepleisterde graf vol dorre doodsbeendere.

Ons verwerp insgelyks die praktyke van liggaamsbouklubs wat liggaamsverafgoding in die hand werk en wat deur bemiddeling van skoonheidsparades die keuse van skoonheidskoninginne aanmoedig.

Ons is beslis gekant teen die ten toppunt gevoerde sportprestasies wat in rekordslaan ontaard. Ons wil ons beywer om die basiese vaardighede tot sportbeoefening as middel tot vryetydsbesteding, te bevorder, maar waak teen oordrewe sportverheerliking wat op die sensasielus van die onskuldige publiek teer en dit vir ekonomiese voordeel uitbuit.

Positief gestel wil ons ons beywer vir staatkundige selfverdediging, die aankweek van opelug-verkeer om die liefde tot die bodem te bevorder; volkome beheer oor 
die fundamentele liggaamlike prosesse en motoriek; vir 'n passende liggaamshouding as beelddraer, daar houding immers ook wesensuitdrukking is. Maar beslis ons beywer vir.' $n$ harmoniese ontwikkeling van die mens as psigo-fisiese totaliteit.

Om hierdic indirekte doelstelling van die L.O. te begryp wil ons daarop wys dat die liggaam nie maar slegs 'n eenvoudige organisme is wat nou maar net op hierdie ondermaanse dal meegesleep moet word om eenvoudig te bly lewe nie, maar dat dit ook uitdrukkingsmiddel is van ons geestelike houding en verrigtinge, tewens 'n middel is om ons geestelik te vorm en te verryk. Dit is dus nic slegs 'n instrument wat ons by tyd en wyle soms bewus gebruik nie, maar 'n wesensdeel waardeur die mens as mens bestaan en funksioneer.

Om die liggaam te ontwikkel as sinvolle natuurlike uitdrukkingsveld van die menslike gees tot 'n gestalte, is dus vir my die kernprobleem van die Liggaamlike Opvocding.

Blocmfontein.

I. R. van der Merwe. 